\title{
ANTIPROLIFERATIVE AND ANTIOXIDANT EFFECTS OF ERUCA SATIVA (JARJEER) LEAVES EXTRACT ON CARCINOMA OF WOMEN'S BREAST
}

\author{
SAFAA A DERBALA ${ }^{1}$, MANAR E ELKADY ${ }^{1}$, REHAB A ELBANHAWY ${ }^{1}$, ABDEL-AZIZ AF ${ }^{2}$ \\ ${ }^{1}$ Urology and Nephrology Center, Mansoura University, Egypt. ${ }^{2}$ Department of Biochemistry, Faculty of Science, Mansoura University, \\ Mansoura, Egypt. Email: manarbio2005@yahoo.com
}

Received: 07 October 2020, Revised and Accepted: 07 December 2020

\section{ABSTRACT}

Objective: This work aims to investigate the influence of Eruca sativa leaves extract on the cell viability of the breast carcinoma cell line (MCF-7).

Methods: In vitro, breast cancer cell line (MCF-7) treated by E. sativa leaves extract for $48 \mathrm{~h}$. The cell viability, proliferation, and apoptosis were assessed using colorimetric (3-(4,5-dimethylthiazol-2-yl)-2,5-diphenyltetrazolium bromide assay, flow cytometric technique, and antioxidant enzymes (superoxide dismutase [SOD] and catalase [CAT]) measurement.

Results: This study demonstrated that the incubation of MGF-7 cells with E. sativa for $48 \mathrm{~h}$ caused a significative reduction in cell viability and proliferation of MGF-7 cell line. In parallel, E. sativa treatment induces a significant increase in apoptosis of MGF-7 cells compared to control. Moreover, flow cytometry analysis demonstrated that the inhibition of MGF-7 cell proliferation existed at the G2 and M phase in the cell-division cycle. Finally, the intracellular antioxidant enzymes SOD and CAT activities were significantly increased in the administered cells compared with unadministered MCF-7 cells.

Conclusions: Taken together, E. sativa treatment reduces cell viability and proliferation concomitant with enhanced antioxidant enzymes expression and apoptosis of breast cancer cell line MGF-7. This may help in protection from breast cancer or preclinical recommendation.

Keywords: Eruca sativa, Cell line of breast cancer, Apoptosis, DNA fragmentation, Antioxidants.

(C) 2021 The Authors. Published by Innovare Academic Sciences Pvt Ltd. This is an open access article under the CC BY license (http://creativecommons.org/ licenses/by/4.0/) DOI: http://dx.doi.org/10.22159/ajpcr.2021v14i2.39937. Journal homepage: https://innovareacademics.in/journals/index.php/ajpcr

\section{INTRODUCTION}

Carcinoma of the breast is the second overriding reason for mortality in womenfolk. Breast cancer incidence rates were $32.0 \%$ followed by hepatocellular carcinoma (13.5\%) among females in Egypt [1]. Medicinal herbs are regarded as the key sources of bioactive compounds that can be utilized for the medical management of varied diseases such as cancer. However, among the 250,000-500,000 herb sorts on land, only $1-10 \%$ has been examined by chemical and pharmaceutical experts for their potentiality and medicative worth, particularly for chemotherapy impact [2]. Eruca sativa or rocket is an "endemic" sort of the Cruciferae and productized chiefly in lands that surround the Mediterranean Sea [3]. The rocket contains great quantities of ascorbic acid and antioxidant compounds [4]. The previous studies reported that rocket species exhibit many medicinal possessions. Consistently, arugula salad types have now been proven a valuable resource for antioxidant complexes, as a rich source of three essential vitamins such as vitamin C, tetraterpenoids, and polyphenols [5]. Importantly, several studies suggested a relationship between the potential to reduce the chance of some specific types of carcinoma and augmented consumption of Cruciferae vegetables, composing their rich sources [6]. The present study aims to evaluate the in vitro antitumor activity of alcoholic extract of $E$. sativa leaves on the cell viability of the breast carcinoma cell line (MCF-7). As well as antioxidant, activities of E. sativa leaf extracts were evaluated.

\section{METHODS}

\section{Preparation of the alcoholic extract of E. sativa leaves}

One hundred and ten gram powder of shade dried leaves of E. sativa was extracted with $75 \mathrm{ml}$ of $95 \%$ ethanol. After that, the mixture was shacked, using a magnetic stirrer for $3 \mathrm{~h} /$ day and allowed to stand for $21 \mathrm{~h}$ for 3 days. Then, the mixture was filtered on Whatman filter paper
$0.45 \mu \mathrm{m}$, and the extract was dissolved in $450 \mathrm{ml} 95 \%$ ethanol and filtered again. The dissoluble ethanol extract was condensed to dryness at $60^{\circ} \mathrm{C}$ under low pressure. Dissolvent eradication of the resultant ethanol extract was weighed $13.5 \mathrm{~g}$. The percent yield was computed utilizing the following form: (weight of extract/original weight $\times 100$ giving $12.27 \%$ yields) of green fatty crude E. sativa leaf ethanol extract. The herbal extract was kept in the fridge and was suspended in distilled water before administration [7].

\section{Cell line}

MCF-7 mammary bust carcinoma cell-division line (ER+) got acquired from initial malignant tumor of a case, but cell line was purchased from the Research and Development of Medical Experimental Research Center, Kafrelsheikh University. Cells were expanded and raised in an adherent culture in minimum essential medium supplemented with $10 \%(\mathrm{v} / \mathrm{v})$ fetal bovine serum, $1 \mathrm{mM}$ Pyruvic Acid Sodium Salt, $10 \mu \mathrm{g} / \mathrm{ml}$ beef insulin, and $1 \%(\mathrm{v} / \mathrm{v}$ ) antibiotic-antimycotic agent. Cells were raised until $37^{\circ} \mathrm{C}$ confluence in a moistened climate of $5 \% \mathrm{CO}_{2}$ in the ambient ether and were passed out once a week with $0.25 \%$ trypsin.

\section{Cell lysate preparation}

MCF-7 cells got placed into 12 -well dishes at $5 \times 106$ cells/well and permitted attachment for $48 \mathrm{~h}$. MCF-7 human breast carcinoma cells were incubated for $48 \mathrm{~h}$ with the $50 \%$ inhibitory concentration ( $\mathrm{IC}_{50}$ ) level of treated cells while comparison cells were incubated with vehicle only. After incubation, trypsin was utilized to assemble cells, flushed 3 times with phosphate-buffered saline (PBS) (pH 7.4) and the pieces were transmitted into extract solution that comprised $20 \mathrm{mM}$ potassium phosphate buffer ( $\mathrm{pH} \mathrm{7})$ and a protease inhibitor cocktail. The cells were homogenized and centrifuged at $10,000 \mathrm{rpm}$ at $4^{\circ} \mathrm{C}$ for $10 \mathrm{~min}$. The resulting supernatant will be used for the measurement of antioxidant enzymes activity. 
(3-(4,5-dimethylthiazol-2-yl)-2,5-diphenyltetrazolium bromide (MTT) assay

The inhibition of MCF-7 cell proliferation on medical treatment with test sample was set by the MTT assay according to the method of Oka et al. [8] using (Sigma Aldrich Chemical Company, UK) MTT assay kit. The rationale of this way is built upon cellular reduction of MTT to an azure formazan result by dehydrogenases of mitochondria of living cells. The blue color intensity made by this process is proportionate to the number of living cells. Trypan Blue $(0.4 \%)$ melted in PBS was utilized to count cells. $0.2 \mathrm{ml}$ trypsin-suspended cell was placed into $0.3 \mathrm{ml}$ medium and $0.5 \mathrm{ml}$ 0.4\% Trypan Blue. Cells were reckoned with a hemocytometer after $5 \mathrm{~min}$. Cells were seeded down into a 96well dish with density $5 \times 103$ cells/well and incubated $\left(37^{\circ} \mathrm{C}\right.$ and $5 \%$ $\mathrm{CO}_{2}$. After $24 \mathrm{~h}$, media was substituted by new media encompassing variant concentrations of test samples and incubated for another $24 \mathrm{~h}$ comparison cells administered with intermediary only were placed to the same dish. Ten microliters of $5 \mathrm{mg} / \mathrm{ml}$ MTT solution were added for each one and these dishes were enwrapped with the tin sheet and incubated for $3 \mathrm{~h}$. Then, the intermediary was taken away and the remnant cells were melted in dimethyl sulfoxide. The absorbency was gauged at $595 \mathrm{~nm}$. The mean values for the absorbance of the ones incubated with test specimens were compared to the mean worth for the absorbance of the comparison cells to compute the per cent of living cells (\% of comparison cells) and when subtracted from 100 give the $\%$ of cell death (inhibition). The outcomes were given as the average \pm SE of three independent experiments; each repeated 3 times.

\section{Assay for apoptosis and DNA damage}

Programmed cell death (apoptosis) and damaged DNA were observed by utilizing an Annexin V-Fluorescein isothiocyanate (V-FITC) apoptosis detection kit (BD Pharmingen ${ }^{\mathrm{TM}}$, USA). Administered and comparison cells were flushed two occasions with PBS and re-suspended in a 1-fold binding buffer at a concentration determined to be $1 \times 106$ cells $/ \mathrm{ml}$. Five microliters of Annexin VFITC Conjugate and $10 \mu \mathrm{L}$ of propidium iodide (PI) solution were added to $500 \mu \mathrm{L}$ of each cell suspension, incubated for $10 \mathrm{~min}$ at ambient temperature and then analyzed by flow cytometry instrument (FAC Star caliber, Becton Dickinson, USA) utilizing excitation at $488 \mathrm{~nm}$ and a $515 \mathrm{~nm}$ bandpass filter for FITC detection and a filter over $600 \mathrm{~nm}$ for PI detection. The percentage of cells in each stage was computed with the software Cell Quest [9].

\section{Assays of superoxide dismutase (SOD) and catalase (CAT)}

Determination of SOD activity was done using kit commercially available (Bio diagnostic, Cairo, Egypt). The SOD activity depends on its ability to inhibit the phenazine methosulfate-mediated reduction of nitro blue tetrazolium dye [10]. CAT activity was also determined by a ready-for-use colorimetric kit (Bio diagnostic, Cairo, Egypt). The CAT activity relies on the ability of the enzyme to react with a known quantity of $\mathrm{H}_{2} \mathrm{O}_{2}$. The reaction is stopped after exactly $1 \mathrm{~min}$ with CAT inhibitor. In the presence of peroxidase (horseradish peroxidase), remaining $\mathrm{H}_{2} \mathrm{O}_{2}$ reacts with 3, 5-Dichloro -2-hydroxybenzenesulfonic acid and 4-aminophenazone to form a chromophore with color intensity inversely proportional to the amount of CAT in the original sample [11]. These assays were done agreeable to the instructions provided by the manufacturer. SOD and CAT activities in each specimen were expressed as $\mathrm{U} / \mathrm{ml}$.

\section{Statistical analysis}

Data were analyzed utilizing IBM SPSS statistics 21 (SPSS Inc., Chicago, Illinois, USA). They were shown as mean \pm standard division. Independent sample t-test was utilized to measure variations between groups. Level of significance for probability value was $<0.05$ as well as $<0.01$ and $\mathrm{p}<0.001$ signified a highly significant result.

\section{RESULTS}

Our study assessed the cytotoxicity of E. sativa affected MGF-7 cells by MTT assay. Forty-eight hours after treatment with E. sativa, the incubation of MGF-7 cells with E. sativa for $48 \mathrm{~h}$ brought about a reduction in the viable cell, with approximate $\mathrm{IC}_{50}$ of $41.13 \mu \mathrm{g} / \mathrm{mL}$. The IC ${ }_{50}$ was $41.13 \pm 0.03 \mu \mathrm{g} / \mathrm{mL}$. In parallel, E. sativa dose-dependently impeded cell line proliferation MGF-7 (Fig. 1).

Herein, the ability of E. sativa to induce apoptosis was examined using Annexin V-FITC apoptosis kit. Our analysis of flow cytometry of Annexin V-FITC showed that showed a significant increase in apoptosis of MGF-7 cells $(55.5 \pm 3.6) \%$ treated by the E. sativa alcoholic extract for $48 \mathrm{~h}$ in compared with untreated MGF-7 cells as control $(8.5 \pm 0.5) \%$ (Table 1 and Fig. 2).

To find out extra info on the machinery behind the growth inhibition effects of E. sativa cell on MGF-7 cell-cycle distribution, we used flow cytometry techniques. Forty-eight hours after treated with E. sativa, our analysis of flow cytometry demonstrated that the inhibition of MGF-7 cell proliferation existed at the $\mathrm{G} 2$ and $\mathrm{M}$ phase cell-division cycle, as reflected with a larger number of accumulated cells (Table 1 and Fig. 3). Specifically,

Table 1: Assessment of cell-division cycle and induction of apoptosis in MCF-7 cells administered with Eruca sativa after $48 \mathrm{~h}$

\begin{tabular}{llll}
\hline Parameters & $\begin{array}{l}\text { MCF-7 cell } \\
\text { line }\end{array}$ & $\begin{array}{l}\text { MCF-7 cell line } \\
\text { treated }\end{array}$ & p value \\
\hline Sub G1 & $62.5 \pm 2.9$ & $16.6 \pm 2.2$ & $0.000^{* * *}$ \\
G0 & $24.5 \pm 1.9$ & $35.9 \pm 3.4$ & $0.014^{*}$ \\
S phase & $3 \pm 0.5$ & $12.5 \pm 1.4$ & $0.003^{* *}$ \\
G2M & $7.8 \pm 1.5$ & $34.2 \pm 0.7$ & $0.000^{* * *}$ \\
Necrotic cell & $8.5 \pm 1.2$ & $21.1 \pm 5.6$ & $0.019^{*}$ \\
Apoptotic cell & $8.5 \pm 0.5$ & $55.5 \pm 3.6$ & $0.000^{* * *}$ \\
Viable cell & $69.9 \pm 1.4$ & $14.0 \pm 0.7$ & $0.000^{* * *}$ \\
Early apoptotic cell & $13.0 \pm 0.6$ & $9.7 \pm 1.8$ & 0.07 \\
\hline
\end{tabular}

Data are presented as mean \pm standard division. Comparison of MCF-7 cell line treated with MCF-7 cell line non-treated as control group. ${ }^{*} \mathrm{p}<0.05$ and ${ }^{* *} \mathrm{p}<0.01$ were considered significant differences, while $* * * p<0.001$ was highly significant

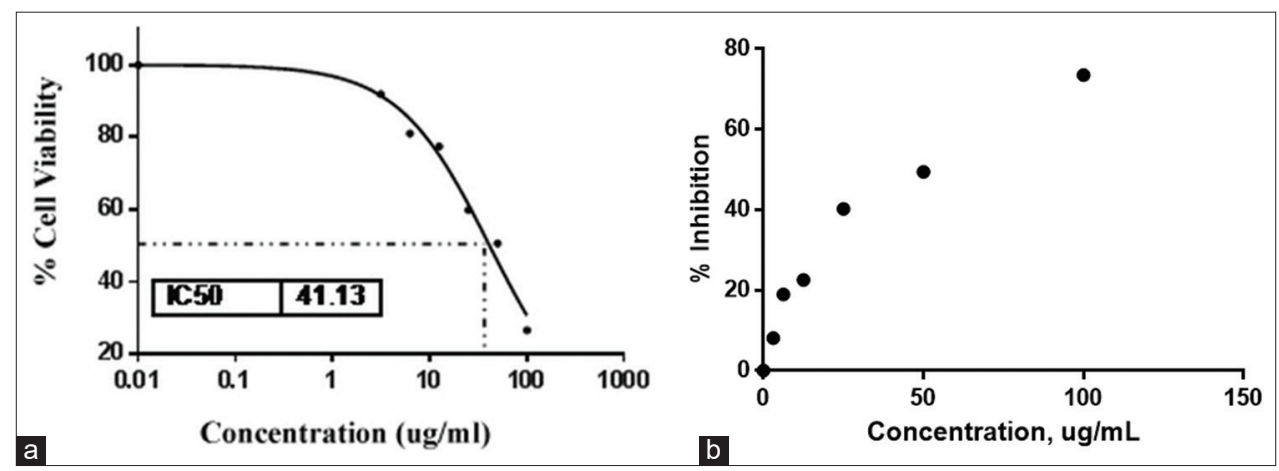

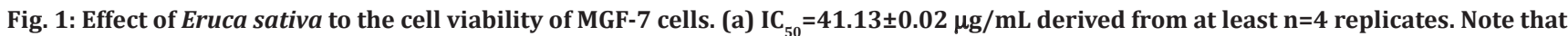
the incubation of MGF-7 cells with E. sativa for $48 \mathrm{~h}$ caused a diminish in living cell, with approximative IC ${ }_{50}$ of $41.13 \mu \mathrm{g} / \mathrm{mL}$. (b) shows that E. sativa dose dependently inhibited the proliferation of MGF-7 cell line 


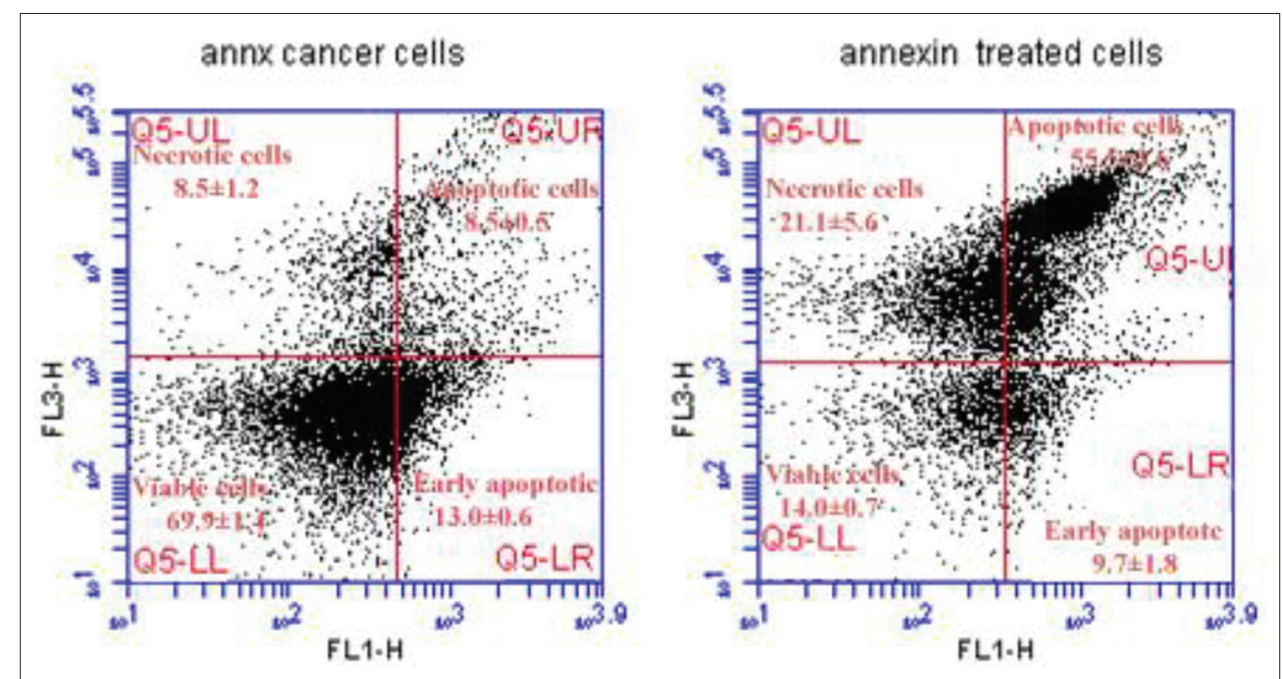

Fig. 2: Quadrant statistical analysis of flow cytometry of Annexin V-FITC. Note, a significant increase in apoptosis of MGF-7 cells (55.5 \pm 3.6 ) $\%$ treated by the Eruca sativa alcoholic extract for $48 \mathrm{~h}$ in compared with untreated MGF-7 cells as control (8.5 \pm 0.5$) \%$

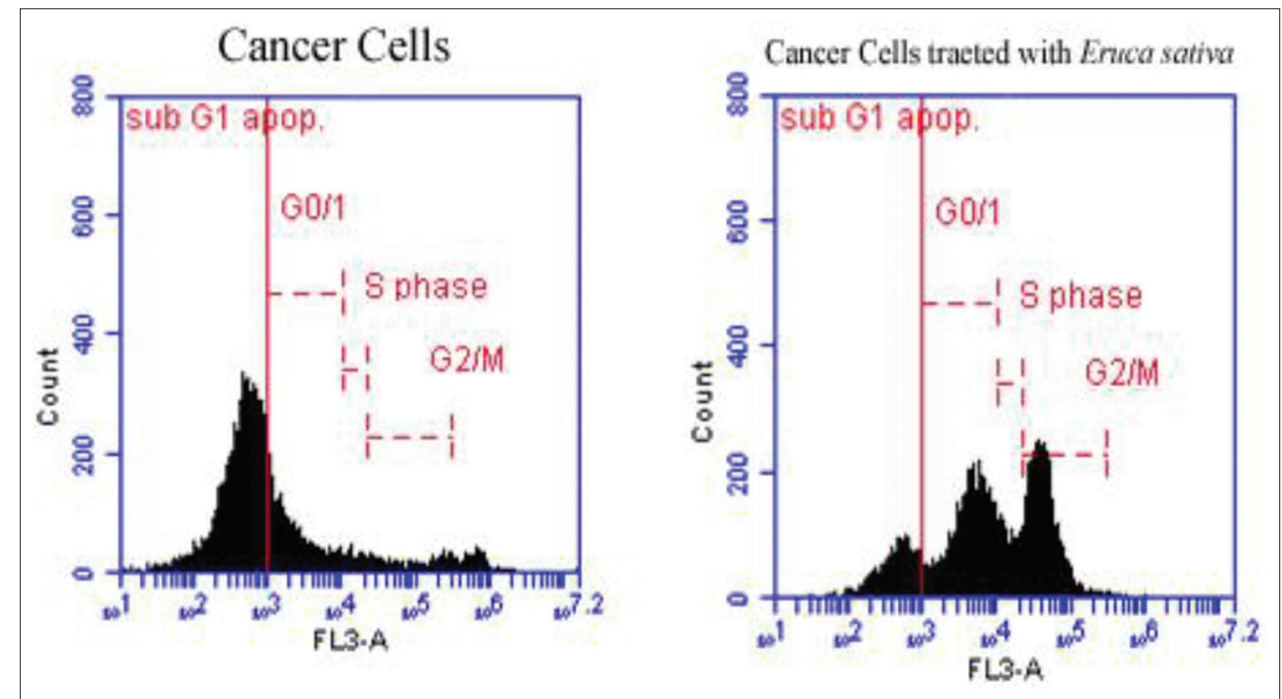

Fig. 3: Assessment of cell-division cycle and induction of apoptosis in MCF-7 cells administered with Eruca sativa after 48 h. Cell-division cycle assay, cell-cycle distribution of MCF-7 cells was analyzed by flow cytometry. Note that the inhibition of MGF-7 cell proliferation happened at the G2 and M stage of the cell cycle, as reflected with a larger number of accumulated cells

$7.8 \pm 1.5 \%$ of the comparison ones were cumulated in the $\mathrm{G} 2$ and $\mathrm{M}$ phases, while $34.2 \pm 0.7 \%$ of the cells were discovered in the $\mathrm{G} 2$ and $\mathrm{M}$ phases in the treated cells with E. sativa. The mean histogram plot of cell-division cycle analysis also signified that E. sativa treatment induced an accumulation of MGF-7 cells in G2 and M phases with the accompaniment of losses from Sub G1 stage. These outcomes implied that E. sativa brought about a stopping point in the cell cycle in G2/M phases.

The antioxidant defense system abilities and oxidative degradation were assessed of MCF- 7 cells by measuring SOD and CAT which play a key part in the cellular antioxidant defense machinery. These enzymes actions in MCF-7 cell-division line were mining augmented $48 \mathrm{~h}$ following E. sativa treatment compared with controls $(\mathrm{p}<0.001)$ (Table 2).

\section{DISCUSSION}

Carcinoma of Women's Breast is still the dominant mode of death worldwide. The carcinoma therapy main objective is to reach maximal remedial destruction of tumor cells utilizing the least concentration of the dose. A significant portion of the work on a plant-based diet and carcinoma prevention gives ground for expecting the virtually helpfully
Table 2: Effect of Eruca sativa on the actions of intracellular enzymatic antioxidant SOD and CAT within MCF-7 cells

\begin{tabular}{llll}
\hline Parameters & MCF-7 cell line & MCF-7 cell line treated & p value \\
\hline CAT $(\mathrm{U} / \mathrm{ml})$ & $1.26 \pm 0.11$ & $2.14 \pm 0.15$ & $<0.001^{* * *}$ \\
SOD $(\mathrm{U} / \mathrm{ml})$ & $1.64 \pm 0.12$ & $2.06 \pm 0.11$ & $<0.001^{* * *}$ \\
\hline
\end{tabular}

Data are presented as mean \pm standard division. Comparison of MCF-7 cell line treated with MCF-7 cell line non-treated as control group. ${ }^{* * *} \mathrm{p}<0.001$ was highly significant

impact of high cruciferous veggies recipes [12]. Here, the incubation of MGF-7 cells with E. sativa for $48 \mathrm{~h}$ significantly showed reduced cell viability and proliferation. Furthermore, E. sativa treatment of MGF-7 cells increased G2/M accumulation increased the actions of intracellular enzymatic antioxidant (SOD and CAT). In general, our result simply that E. sativa induces apoptosis and $\mathrm{G} 2 / \mathrm{M}$ arrest concomitant with reduced cell viability and proliferation in breast cancer MGF-7 cells line.

The cytotoxic action on mammary tumor cell lines defined agreeable to the dosage values of medications exposure required to diminish survivor 
cell lines to $50 \%\left(\mathrm{IC}_{50}\right)$. We found that MCF7 cell line treatment with E. sativa increased cytotoxic activities as reflected with inhibition of cell proliferation in a time-dependent manner with an $\mathrm{IC}_{50}$ of $41.13 \mu \mathrm{g} / \mathrm{ml}$. This may suggest its anticancer potential. These findings confirm with the past study by Michael et al. [12] showed that $\mathrm{IC}_{50}(\mu \mathrm{g} / \mathrm{ml})$ of $70 \%$ aqueous ethanolic extract of $E$. sativa on MCF7 cell line was 21.7. While, Azarenko et al. [13] indicated that the main isothiocyanate Erucin existed in arugula species (cabbage, cauliflower, kale, arugula, E. sativa) were inhibited MCF7 cell proliferation in a time-dependent manner with $50 \%$ inhibition the $\mathrm{IC}_{50}$ that happens at a concentration of $28 \mathrm{mM}$. Pawlik et al. [14] found that MCF7 cells after $96 \mathrm{~h}$ of treatment with E. sativa IC50 were $9.7 \mu \mathrm{M}$. This may suggest the anticancer potential of $E$. sativa.

The arrest of cell-division cycle progression is recognized as a stopping point in the cell-division cycle transition such as G0, G1, S, and G2/M stages for cell reduplication and subdivision. In the current study, E. sativa effectively induced G2/M arrest. Hence, cell cycle growthinhibitory at G2M by E. sativa was accompanied by the arrest in mitosis. Since both non-cancerous cell and cancerous cell proliferation is contingent on the cell-division cycle in well-balanced, many composites that act against cancer, brought about an extended mitotic arrest through induced cell G2/M arrest [15].

It illustrated that E. sativa might be a suitable candidate as described previously for breast cancer therapy as long as it induced conditions of oxidative stress in MCF-7 cells. There was an enhancement in the actions of SOD and CAT. Our investigation exhibited that E. sativa augmented the action of cellular SOD and CAT in $48 \mathrm{~h}$. This may be due to an increase in free radicals contribute to augment in action and plane of enzymatic antioxidant. The antioxidants activity of $E$. sativa is due to the presence of polyphenols contents [5]. The present findings agree with the past study by Alam et al. [16] demonstrated that E. sativa seeds have antioxidant action and do a preventive impact on Mercury (II) chloride-induced nephrotoxicity. Consistently, Hussein et al. [17] reported that the extracts of E. sativa in ethanol increasing/preserving the plane of antioxidant molecules and enzymatic antioxidant in rats with an ethanol-induced liver injury.

\section{CONCLUSION}

In summary, the incubation of MGF-7 cells with E. sativa for $48 \mathrm{~h}$ significantly showed reduced cell viability and proliferation. Furthermore, E. sativa treatment of MGF-7 cells increased G2/M accumulation increased the actions of intracellular enzymatic antioxidant SOD and CAT. In general, our results imply that E. sativa brings about apoptosis and G2/M arrest concomitant with reduced cell viability and proliferation in breast cancer MGF-7 cells line this may help in clinical pretreatment and protection for breast cancer.

\section{AUTHORS' CONTRIBUTIONS}

All authors participated equally in this research work.

\section{AUTHORS' FUNDING}

This study was self-funded.

\section{CONFLICTS OF INTEREST}

The authors declare that they have no conflicts of interest.

\section{REFERENCES}

1. Ibrahim AS, Khaled HM, Mikhail NN, Baraka H, Kamel H. Cancer incidence in Egypt: Results of the national population-based cancer registry program. J Cancer Epidemiol 2014;2014:437971.

2. George VC, Kumar DR, Kumar ND, Rajkumar V, Suresh P, Kumar RA. Quantitative assessment of the relative antineoplastic potential of the n-butanol leaf extract of Annona muricata Linn. In normal and immortalized human cell lines. Asian Pac J Cancer Prev 2012;13:699-704.

3. Barlas NT, Irget ME, Tepecik M. Mineral content of the rocket plant (Eruca sativa). Afr J Biotechnol 2011;10:14080-2.

4. El-Wakeel MA, El-Desoki ER, Ahmed SE. Bioherbicidal activity of Eruca sativa fresh shoot aqueous extract for the management of two annual weeds associating Pisum sativum plants. Bull Natl Res Centre 2019;43:87

5. El-Fadaly H, El-Kadi S, El-Moghazy M, Soliman A, El-Haysha M. Antioxidant activity studies on extracts of Eruca sativa Seed meal and oil, detoxification, the role of antioxidants in the resistant microbes. Hum J 2017;6:31-51.

6. Radziejewska-Kubzdela E, Olejnik A, Biegańska-Marecik R. Effect of pretreatment on bioactive compounds in wild rocket juice. J Food Sci Technol 2019;56:5234-42.

7. Alqasoumi S. Carbon tetrachloride-induced hepatotoxicity: Protective effect of Rocket Eruca sativa L. in rats. Am J Chin Med 2010;38:75-88.

8. Oka M, Maeda S, Koga N, Kato K, Saito T. A modified colorimetric MTT assay adapted for primary cultured hepatocytes: Application to proliferation and cytotoxicity assays. Biosci Biotechnol Biochem 1992;56:1472-3

9. Fabisiak JP, Borisenko GG, Kagan VE. The quantitative method of measuring phosphatidylserine externalization during apoptosis using electron paramagnetic resonance (epr) spectroscopy and annexinconjugated iron. Methods Mol Biol 2014;1105:613-21.

10. Nishikimi M, Roa NA, Yogi K. The occurrence of superoxide anion in the reaction of reduced phenazine methosulfate and molecular oxygen. Biochem Biophys Res Commun 1972;46:849-54.

11. Aebi H. Catalase in vitro. Methods Enzymol 1984;105:121-6.

12. Michael HN, Shafik RE, Rasmy GE. Studies on the chemical constituents of the fresh leaf of Eruca sativa extract and its biological activity as an anticancer agent in vitro. J Med Plants Res 2011;5:1184-91.

13. Azarenko O, Jordan MA, Wilson L. Erucin, the major isothiocyanate in arugula (Eruca sativa), inhibits proliferation of MCF7 tumor cells by suppressing microtubule dynamics. PLoS One 2014;9:1-12.

14. Pawlik A, Skan Wojewódzka MS, Herman-Antosiewicz A. Sensitization of estrogen receptor-positive breast cancer cell lines to 4-hydroxytamoxifen by isothiocyanates present in cruciferous plants. Eur J Nutr 2016;55:1165-80.

15. Ang E, Pavlos N, Chim S, Feng HT, Scaife RM, Steer JH, et al. Paclitaxel inhibits osteoclast formation and bone resorption via influencing mitotic cell cycle arrest and RANKL-induced activation of NF-kappaB and ERK. J Cell Biochem 2012;113:946-55.

16. Alam MS, Kaur G, Jabbar Z, Javed K, Athar M. Eruca sativa seeds possess antioxidant activity and exert a protective effect on mercuric chloride-induced renal toxicity. Food Chem Toxicol 2007;45:910-20.

17. Hussein J, Salah A, Oraby F, Nour El-Deen A, El-Khayat Z. Antihepatotoxic effect of Eruca sativa extracts on alcohol-induced liver injury in rats. J Am Sci 2010;6:381-9. 